\title{
Assessment of the vulnerability of industrial parks to flood in South Korea
}

\author{
JiEun Ryu ${ }^{1}$ Dong Kun Lee ${ }^{1,2}$ - Chan Park ${ }^{3}$ Yoonjung Ahn ${ }^{4}$. \\ Seehyung Lee ${ }^{5} \cdot$ Kwanglim Choi $^{5} \cdot$ TaeYong Jung $^{6}$
}

Received: 21 October 2014/Accepted: 30 January 2016/Published online: 7 March 2016

(C) The Author(s) 2016. This article is published with open access at Springerlink.com

\begin{abstract}
Since recently, the potential of torrential downpour is increased and the flood damage shows increasing trend, in this study, the method to assess the flood vulnerability was established for the industrial parks, which is the driving power of the economic growth in Korea, and the results were analyzed. The vulnerability of each industrial parks was analyzed using three indicators: climate exposure, sensitivity and the adaptation ability, and the indicator value was calculated by selecting the proxy variable by each indicator. Among the primarily indicators, the final indicators were selected through the site investigation and in-depth interview. The vulnerability assessment was performed not only for the present but for the future (2020s, 2050s and 2100s). In the analysis results, Ulsan Mipo National Industrial Park was the most vulnerable for the present but in 2020s, Gwangyang National Industrial Park and Myeongji-Noksan National Industrial Park in 2050s and 2100 s were assessed as most vulnerable. In the results of flooding vulnerability assessment, south coast industrial parks are the most vulnerable region during baseline and future. In addition, such industrial parks mostly built in the early phase of industrialization and they have advantage in import and export but were represented to be highly vulnerable due to aged infrastructures. In the industrial parks, as the enterprises are concentrated, it is easy to
\end{abstract}

Dong Kun Lee

dklee7@snu.ac.kr

JiEun Ryu

ulygajok@snu.ac.kr

1 Interdisciplinary Program in Landscape Architecture, Seoul National University, Daehak-dong, Gwanak-gu, Seoul, Republic of Korea

2 Department of Landscape Architecture and Rural System Engineering, \#200, College Agricultural Life Science, Seoul National University, Daehak-dong, Gwanak-gu, Seoul, Republic of Korea

3 Department of Landscape Architecture, University of Seoul, Seoul, Republic of Korea

4 Korea Environment Institute, Seoul, Republic of Korea

5 Business Institute for Sustainable Development, The Korea Chamber of Commerce and Industry, Seoul, Republic of Korea

6 Graduate School of International Studies, Yonsei University, Seoul, Republic of Korea 
exchange the information and logistics, but the damage of natural disasters due to flooding can be aggravated due to the characteristics of the concentration. Actually, there are some cases that the industrial parks and the enterprises received the flooing damage in the highly vulnerable area by the torrential downpour. In this study, the vulnerability assessment was performed for the flooding damage by the torrential downpour for the industrial parks and the potential that the this study can be used as a useful decision-making tool in deciding the priority of adaptation ability was confirmed.

Keywords Climate change $\cdot$ Flooding $\cdot$ Vulnerability assessment $\cdot$ Adaptation Climate exposure $\cdot$ Heavy rain $\cdot$ Industrial parks

\section{Introduction}

The concept of climate change vulnerability originated from natural hazards, which is defined as the response capability or resistance to natural hazards by people or groups (O'Brien and Leichenko 2000; Turner et al. 2003; Fussel and Klein 2006; Janssen et al. 2006). The Intergovernmental Panel on Climate Change (IPCC) defined this vulnerability as "The degree to which a system is susceptible to, or unable to cope with, adverse effects of climate change, including climate variability and extremes. Vulnerability is a function of the character, magnitude, rate of climate variation to which a system is exposed, its sensitivity, and its adaptive capacity" (McCarthy et al. 2001). Ager (2006) suggested that vulnerability assessment is a useful guideline for improving well-being through risk reduction and is an effective tool for the analysis of physical and social systems. Scientists in various fields have studied vulnerability since White and Hass (1975). In recent years, various studies have investigated sustainability along with the concept of vulnerability and resilience (Ager 2006; Smit and Wandel 2006; Aldum et al. 2013).

Climate change adaptation research in local government units has been conducted in the Republic of Korea by the government (Ministry of Environment 2011). According to the Low Carbon Green Growth Act ('10.4), the Climate Change Adaptation System (CCAS) was established as a government agency for climate change policy and scientific research in 2009. The Korean meteorological administrator provides high-resolution future meteorological data using Representative Concentration Pathways (RCPs) scenarios. This research on the effects of climate change to each industry and municipality is being conducted in academia. In recent years, the government successfully attracted the Green Climate Fund (GCF) and held the 6th International Symposium on Climate Change Adaptation at Songdo, Incheon. The Korean government has undertaken various efforts for climate change adaptation at the national level. However, because of the increased damage caused by climate change in the industrial sector, the government began to establish a national climate impact assessment and adaptation policies.

Industrial parks have functioned as hotspots to achieve economic development (Han 2007). Distributed companies were integrated in industrial parks, and Korea now has internationally competitive manufacturing (Kim 2011). Because enterprises have been located in industrial parks, they could use infrastructure and share technology and information with other corporations. The government provides tax support and reduces loan interest. The advantage of being located in industrial parks is minimizing the social and environmental costs by increasing the efficiency of land use (Korea Industrial Complex 
Corporation 2014). If a natural disaster occurs at an industrial park, then serious damage would occur. Sudden strong rains occurred in the Gunsan National Industrial Park, producing over $30 \mathrm{~mm} / \mathrm{h}$ of rain, and the Gwangyang National Park was flooded by an unexpected hurricane (http://onkweather.com/bbs/board.php?bo_table=eco2\&wr_id=488).

The law provided to perform the disaster impact assessment in advance to prevent the damage to the industrial park by the natural disaster at the national level (Public Notice No. 2012-47 of Central Disaster and Safety Countermeasures Headquarter). However, this assessment is nothing but the formal procedure to analyze the potential damage by the storm and flood in the area using the climate data in the past and to establish the countermeasures when the new industrial park is built. Since it is based on the data of the past, it cannot reflect the variability according to the future climate change and is the assessment corresponded to the new industrial park. Therefore, to reduce the damage by the natural disaster caused by the climate change, existing industrial park should perform the vulnerability assessment by the climate change from the industrial park to understand how it is vulnerable to what climate exposure and establish the adaptation measures for them.

However, there are not enough research performed related to that and a few researches have been performed as follows. Kim et al. (2013) assessed the vulnerability of the industrial complex by administrative district. Since this research assessed the actual industrial complex using the proportion of the area, etc. of each local government, it has some limitations, and Mueller et al. (2015) assessed the four tools that assessed the water supply and demand in the automotive industry field. However, it did not address the damage of the industrial factor according to the change of the flood by the overall climate change just mentioning the water supply and demand. Khazari et al. (2013) assessed the industrial and social vulnerability using indicators with the loss by indirect natural disaster. But it does not reflect each climate esposure such as flooding, drought only mentioning about the overall industry even all climate exposure characteristics are different. Tixier et al. (2002) performed the risk analysis by the climate change for the corporations, but since there is the difference in the spatial scale between the individual corporation and the industrial complex, additional researches are needed. Therefore, the purpose of this study is to assess the degree of vulnerability of industrial park and to reduce the degree of vulnerability for present and future by establishing the cost-effective adaptation measures fir to each industrial park.

\section{Materials and methods}

\subsection{Assessment of vulnerability}

The assessment of vulnerability measures the potential effects of climate change through climate exposure and sensitivity, and the adaptation ability was additionally considered before finally assessing the vulnerability of each industrial park. The sensitivity and adaptation ability require socioeconomic scenarios for the future. Regarding the vulnerability assessment, IPCC (2007) defined the climate exposure as the climate change factors (severe cold, drought, typhoon, etc.), the sensitivity as the degree of influence to system by climate disturbance and the adaptation ability as the control action of the nature and social system in response to the influence of climate change. In this study, the assessment of vulnerability was performed focusing on field of industry according to such concept. In this study, we conducted a study focused on the floods caused by torrential rains. 
Because of the large uncertainty that these scenarios entail, the current state was assumed to continue in the future. The current status data of eight industrial parks, including inland and coastal areas, were used in the assessment. This study used the vulnerability assessment methodology of the IPCC (2007), which is based on indices and in-depth interviews.

\subsection{Data}

The climate exposure assessment values were established using the RCP scenarios from the Korea Meteorological Administration (KMA). The 5th IPCC assessment report determined the greenhouse gas concentration as the amount of radiation of the human activities having influences on the atmosphere, and in the RCP scenario, the resolution was updated fit to the recent forecasting model by reflecting the trend of change in the greenhouse gas concentration. RCP scenario is characterised that set the concentration value of greenhouse gas first, then decided to social and economic policies for reducing greenhouse gas emissions. RCP 2.6 scenario means the earth could recover from human effect by itself. RCP 4.5 scenario means the policies of greenhouse gas reduction is implemented well. Policy of greenhouse gas reduction is achieved certain degree is RCP 6.0 scenario. The emissions with the current trend was set to RCP 8.5 scenario.

In Korea, Korea Meteorological Administration estimates the climate change in Korean Peninsula with the dynamical downscaling using the regional climate model with global climate model and provides the data on the temperature and precipitation for future publicly estimating the detailed climate change scenario in South Korea by applying the statistical downscaling technique (homepage of Korea Meteorological Administration) (Kim et al. 2012, 2013).

To reduce uncertainty all of the scenarios of RCP, 2.6, 4.5, 6.0 and 8.5 were used. Furthermore, proxy variables were established to evaluate heavy rains in the present, 2020s

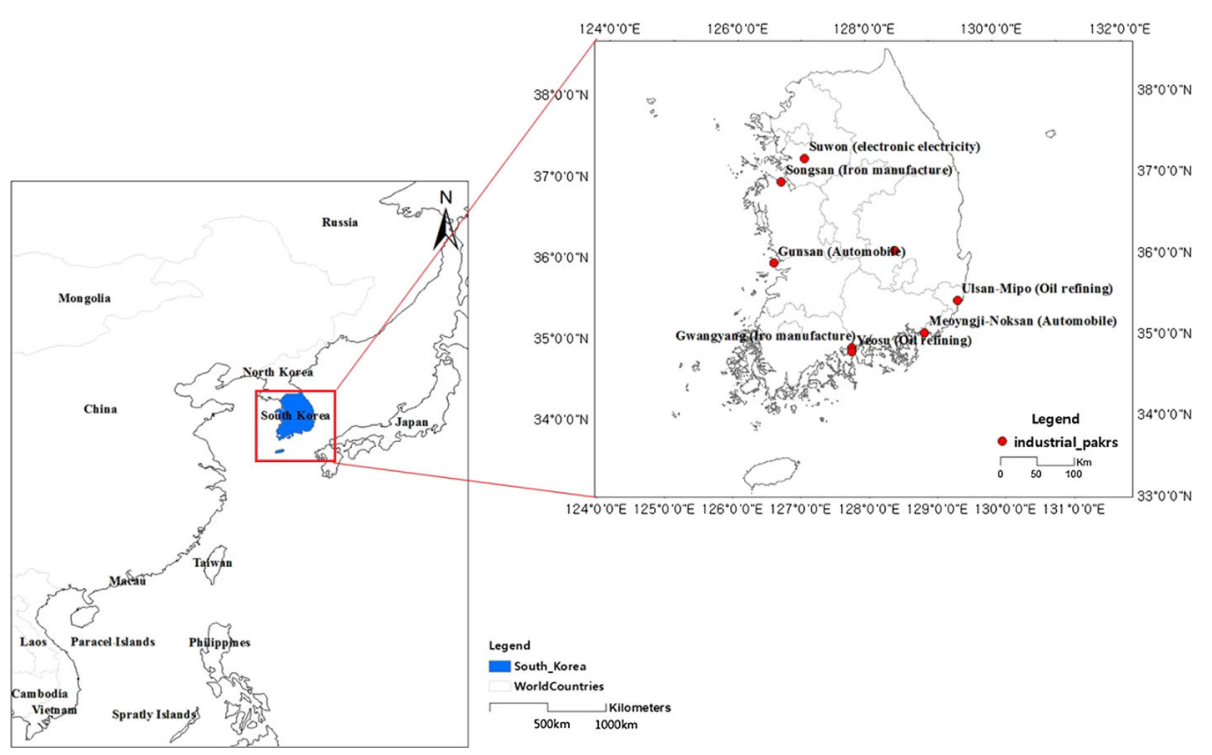

Fig. 1 Study area (industrial parks) 
(average of the values between 2016 and 2025), 2050s (average of the values between 2046 and 2055) and 2100s (average of the values between 2090 and 2099). Because RCP only offers daily data for temperature and precipitation, the climate exposure criteria were set through a literature review, and the climate data for the assessment were created in line with these criteria.

For other data, the Directory of Industrial Complexes from the Korea Industrial Complexes Corporation and field survey data were used. To evaluate indices related to topography, a digital elevation model (DEM) was established as a numerical map that was evaluated through geographical information system (GIS). The Directory of Industrial Complexes is an annual publication that describes the area, opening date, major industries, number of workers, green belt, existence of watershed and other information about each industrial park (Korea industrial complex corporation 2014).

\subsection{Study area}

Industrial parks are highly concentrated areas of companies in similar industries that can share materials and information and receive government support. Industries that have advantages in production because of the concentrated location can be largely divided into electronics, petrochemicals, automobile and steel. In this study, eight industrial parks in four industries were selected considering the representative industries of various industrial parks located in inland and coastal areas (Fig. 1).

In Korea, the industrial parks managed by the state are referred to as national industrial parks and mean the industrial parks designated according to Article 6 of Industrial Site and Development Act to foster the national key industries, the advanced science and technology industries, etc. or to develop the area located in the underdeveloped region or extended across the provinces by two or more metropolitan cities (Article 6, Chapter 3 of Industrial Sites and Development Act).

This study limited to the flood damage because the property damage can occur clearly by the heavy rain. Also, since it is not clear whether the damage by the temperature change, the sea level rise, the heavy snow caused by the factors of the climate change, in this study, the assessment indices were constructed only for the flood out of the various climate exposures. This study was limited to the flood by the torrential downpour, the indices related to the flood were used.

In the national industrial parks, approximately 6200 corporations are located, $32.1 \%$ of the small and medium businesses in Korea are located in the industrial parks as of end of 2012, and at the factory site area basis, approximately $40.6 \%$ of the factory area of entire small and medium businesses are located within the industrial parks (Jo 2005). Particularly, since the $56.1 \%$ of the medium businesses and $32.1 \%$ of the small businesses are located within the industrial parks, if the industrial parks, where those businesses are located, had considered the climate change when they were built, the damage to them would have reduced to minimum.

\subsection{Selection of assessment indices}

The vulnerability assessment indices in the industrial parks to the flooding were drawn first through the literature review and the in-depth interview with the experts in the industry sector. After the establishment of the assessment indices (first: April 1-15, 2012, second: May 1-21, 2012) and two expert meetings (first: August 13, 2013, second: September 2, 2013), the indices were reviewed through in-depth written interviews (November 22, 2013) of four climate change experts. We visited the industrial parks and companies six times 
between September and October 2013 (September 30, October 1, October 2, October 10 and October 11, 2013) and conducted in-depth interviews for $20 \mathrm{~min}$ with each agency, including the Korea Industrial Complex Corporation, Human Resources Development Service of Korea, representative companies (three persons) and the City Hall.

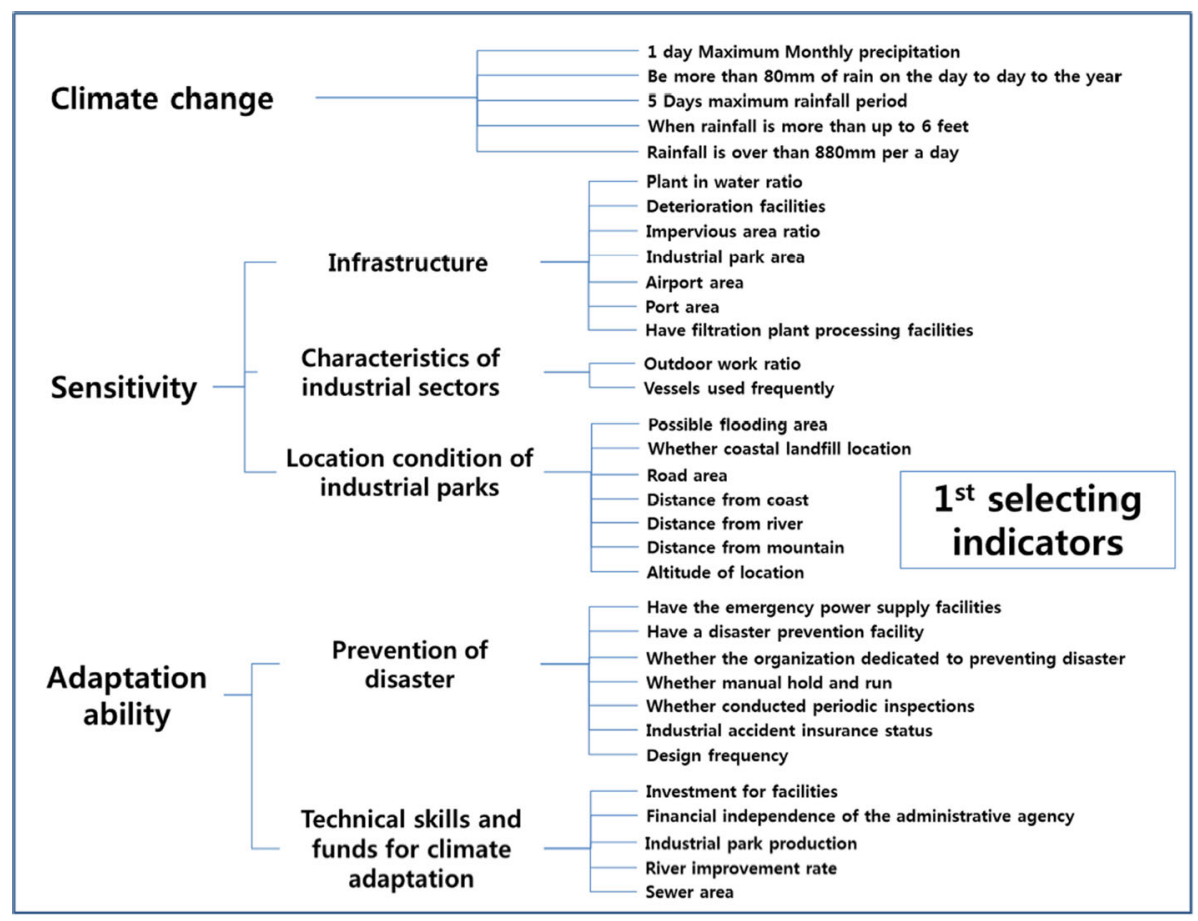

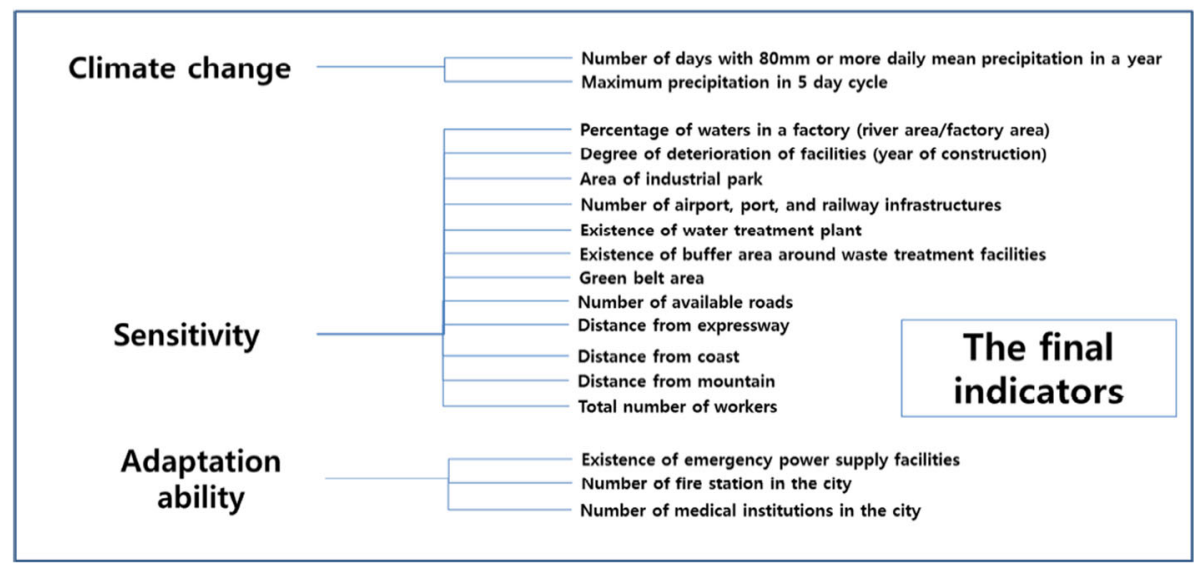

Fig. 2 Final indicators and the process 
The exposure indicators have selected by primary literature review first such as 5 days maximum monthly precipitation (Lee et al. 2012), more than $80 \mathrm{~mm}$ of rain on the day to day to the year (Bae et al. 2013; Lee et al. 2012), 1 day maximum monthly precipitation (Korean Ministry of Knowledge Economy 2010; Lee et al. 2012), more than up to six feet of rainfall (Islam et al. 2013), rainfall over than $80 \mathrm{~mm}$ per year (Han et al. 2007), 5 days maximum rainfall period (Lee et al. 2012), and the number of days with $80 \mathrm{~mm}$ or more daily mean precipitation in a year and the maximum precipitation in 5-day cycle. Selected climate exposure indicators as Number of days with $80 \mathrm{~mm}$ and Maximum precipitation in 5 day cycle except to repetition indicators.

In case of the infrastructure and the locational conditions that depend on the sensitivity, each indicator was drawn through the literature study. The infrastructures, which are the industrial factor, characteristics of each business and the locational conditions were considered. Rivers in the industrial park may be the cause of the flooding when the heavy rains occur (Bae et al. 2013). Deterioration facilities mean that the greater the deterioration, the greater the damage (Bae et al. 2013). Impervious area ratio means that the higher the impervious area, the higher the potential of flood due to greater overflow (Han et al. 2007; Shim and Ji 2012; Bae et al. 2013). Industrial park area means that the greater the area, the greater the risk of damage industrial parks have (Ko 2011). Area of airport and the area of harbors are the infrastructures of the local government having influence on the logistics of the businesses within the industrial parks when the flood occurs, and the greater the area, the more the alternative facilities exist (Kang et al. 2011). As to have filtration plant processing facilities (Shim and Ji 2012), it was judged that as the water can be contaminated by the industrial waste washed away, etc. when the flood occurs, it is important whether they can be treated by the industrial parks (O'brien et al. 2004). Many workers have worked at outside of building for the product and management of production (Leither et al. 2009; Bae et al. 2013). There was no clear standard for making data, this indicators could not selected. In the aspect of the industrial parks location, possible flooding area (Bae et al. 2013) means the physically submersible area. Most of the industrial parks demand the larger land, and in case of the reclaimed land, since it is provided with low price and not need to perform the prior disaster impact assessment, its price tends to be cheap and has advantage in the logistics, and it tends to become the industrial parks site. Whether location of industrial parks on landfill was selected by a final indicator because lowland is the site gathering of waters (Sullivan and Meigh 2005; Bae et al. 2013). To assess the sensitivity as low if there are other paths usable for logistics when it is flooded, the road area was used as indicator (Wall and Marzall 2006; Bae et al. 2013). Since there are the cases that the closer the distance between the industrial parks and the coast, the higher the damage when the high tide and the torrential downpour occur at the same time, the distance from the coast was selected as variable (Wall and Marzall 2006; Bae et al. 2013). In addition, since Myeong and Yi (2009) drew the river, road, harbor, railroad, etc., which are important for logistics, as the vulnerable facility, the distance from river was selected as variable. Since Lee et al. (2012) asserted that as landslide occurs by the torrential downpour, by which the industrial parks may get damaged, it needs to be prevented, and it was reflected with the distance from mountain. In addition, in case of the industrial parks located high ground (Han et al. 2007), as it was judged that the damage by the high tide and the flood would be low, the altitude of location was drawn as the primary variable, among which the percentage of waters in a factory (river area/factory area), the degree of deterioration of facilities (year of construction), the area of industrial park, number of airport, port and railway infrastructures, existence of water treatment plant, existence of buffer area around waste treatment facilities, green belt area (Brooks 2003), number of available roads, 
distance from expressway, distance from coast, distance from mountain, total number for workers were selected as final variables (Sullivan and Meigh 2005).

Gallopin (2006) said that the adaptation ability is "the ability of a system to adjust to climate change (including climate variability and extremes) to moderate potential damages, to take advantage of opportunities, or to cope with the consequences." In this study, the adaptation ability was considered as the ability to endure each climate change and the indicator was constructed with the prevention of disaster and the technical skill and funds for climate adaptation. As the detailed indicator of the disaster prevention system, the investment for facilities (whether there is emergency power supply facilities) (O'brien et al. 2004; Bae et al. 2013) to prepare for the power failure by the flood and the disaster prevention facility (Sullivan and Meigh 2005; Bae et al. 2013), which means the ability to prepare for flooding, were established. If when the floods caused by torrential rains occurred, dedicated organization could cope with this rapid response it is possible (Wall and Marzall 2006; Bae et al. 2013). If a disaster such as a flood evacuation drills in the manual regularly it may be higher adaptive capacity. In addition, to reduce the possibility of damage to the machinery through the regular management, whether the periodic inspection is conducted (Bae et al. 2013) was selected, and to prevent the great damage when the damage occurs, industrial accident insurance status (Bae et al. 2013) was selected as indicator. The design frequency, which is considered when designing the factory, etc. was drawn as the indicator to prepare for each climate exposure. And the final indicators selected through the consultation with the experts were determined as existence of emergency power supply facilities (Wall and Marzall 2006; Yusuf and Francisco 2009), number of fire stations in the city and number of medical institutions in the city (see Fig. 2).

The data for the final indicator drawn were constructed, and the final vulnerability assessment value by industrial complex was drawn by using following vulnerability assessment method. To make the different units and ranges of the individual indicators comparable, the indicator values $M_{i}\left(S_{j}\right)$ are normalized before combining them to one composite indicator (Merz et al. 2013). $V(s)$, the vulnerability assessment value, is calculated by function of Eq. 1. Multiplying the each climate exposure, sensitivity and adaptation ability with each weight. Function of vulnerability is climate exposure plus sensitivity minus adaptation then divided by the sum of each weight. The weight was determined by the expert survey, but in this study, as the difference was insignificant in the results of survey, the assessment was performed by applying the same weight with 1 .

$$
\mathbf{V}(\mathbf{s})=\frac{\left(\alpha\left(\boldsymbol{V}_{1}\right)+\beta\left(\boldsymbol{V}_{2}\right)-\gamma\left(\boldsymbol{V}_{3}\right)\right)}{\alpha+\beta+\gamma}
$$

where $V(s)=$ vulnerability of a system $\mathrm{s} ; \alpha=$ weight of indicator of climate exposure; $\beta=$ weight of indicator of sensitivity; $\gamma=$ weight of indicator of adaptation ability; climate exposure, sensitivity and adaptation ability indices are normalized numbers; $V_{1}=$ climate exposure; $V_{2}=$ sensitivity; and $V_{3}=$ adaptation ability.

The climate exposure, sensitivity and the adaptation ability required to draw the vulnerability value were composed of detailed variables, and the standardization was performed for each indicator, first. Then each variable was added up by indicator, for which the standardization was performed based on the maximum value and minimum value by industrial complex, and the vulnerability value by industrial complex was drawn (Khazari et al. 2013; Merz et al. 2013). 


$$
M_{i}=\sum_{1}^{i} \frac{N_{i}-N_{i}^{\min }}{N_{i}^{\max }-N_{i}^{\min }}
$$

$M_{i}$ is the sum of the value standardized by each indicator and is represented as the value by industrial complex and its range is $0 \leq M_{i} \leq 1$. Each indicator, $N_{i}$, is calculated after standardizing the actual value. The standardization method is same as the calculation method for $V_{i}$ as shown below.

$$
V_{i}=\frac{\left(M_{i}-M_{i}^{\text {min }}\right)}{\left(M_{i}^{\text {max }}-M_{i}^{\text {min }}\right)}
$$

$M_{i}=$ sum of standardized value by each indicator, $V_{i}=$ Indicies $\left(v_{1}=\right.$ climate exposure, $v_{2}=$ sensitivity, $v_{3}=$ adaptation ability) (Khazari et al. 2013).

\section{Results}

The vulnerability is assessed with the function of climate exposure, sensitivity and adaptation ability. In this study, four scenarios were considered for vulnerability assessment, and as each scenario has different assumptions on the greenhouse gas concentration and the corresponding changes in the temperature and the precipitation, the policymakers can judge considering the uncertainty in making decision. However, to compare the values of vulnerability assessment by industrial parks directly, it needs to see the current vulnerability value and the variation of the future value at a glance. In this study, each industrial parks consider four time series and each time series have four vulnerability assessment values because of four RCP senarios. Average of four vulnerability assessment values have used to compare of vulnerable degree according to time serious.

When comparing the values for scenario by period and by industrial parks, in the average standard deviation, Gwangyang National Industrial Park was approximately 0.169, showing the greatest value, and Gumi was approximately 0.057. When comparing the values of scenarios by period, the standard deviation of the climate exposure for 2100 s was approximately 0.142 , showing that the inclination is than that for 2050s (approximately $0.095)$ and 2020s (0.103). Therefore, it was observed that the uncertainty for the scenario for 2100 s is high as the deviation by scenario was represented greater by scenario.

Gwangyang National Industrial park is the largest increase for the vulnerable degree than other regions. In 2020s has shown that approximately $166 \%$ increase compare with current vulnerable value. The industrial park having second greatest increase rate was Yeosu, which was represented to be increased by approximately $31.3 \%$ in 2020 s, by $74.95 \%$ in 2050 s and by $72.62 \%$ in 2100 s compared to the present. In case of Ulsan Mipo National Industrial Park, it was represented to have highest potential of climate exposure now, and in 2020s, it was represented rather to be decreased by $29.95 \%$ in 2020 s and by $20.19 \%$ in 2100 s. Some industrial parks showed the inclination that the potential of climate exposure was represented to be decreased in 2020s only and increased again, Myeongji-Noksan National Industrial Parks was represented to be increased by $9.78 \%$ in 2020 and increased by $15.84 \%$ in 2100 s, Suwon region also was represented by $10.06 \%$ in 2020s and increased by $1.85 \%$ in 2100s, and Songsan Industrial Park was represented to be decreased by $3.33 \%$ in 2020 s but increased by $28.73 \%$ in 2100 s compared to the present. 
In below Table 1, since the value of climate exposure was the mean value drawn by scenario by period, the highest value of the climate exposure is not 1 and 0.538 , which was the highest value in Myeongji-Noksan in 2100s. In addition, as the lowest value also means the mean value of the climate exposure by period, which can occur by each scenario, it is not 0 but 0.180 , which is the value of climate exposure represented in Gumi and Gwangyang (Table 1 ).

Sensitivity was drawn by standardizing the standardized value of each detailed indicator again, and each value is represented as the value from minimum 0 up to maximum 1 . The detailed indicators of the sensitivity drawn finally as mentioned above are shown in Fig. 2. The sensitivity of Myeongji-Noksan was 1, representing the highest, and that of Suwon was 0 , representing the lowest value. In case of Myeonji-Noksan, it is the industrial park built in the early stage and is represented to have highly sensible infrastructures when torrential downpour occurs. In addition, since it has high possibility that the torrential downpour would lead to landslide due to having little buffer area and the mountain around the industrial complex when the torrential downpour occurs, the sensitivity was represented high.

Since Suwon has lots of medical institutions and fire stations compared to other industrial parks, the adaptation ability of Suwon was received the highest assessment. On the contrary, since Songsan is affected by the raise of level and the high tide and low tide together with the torrential downpour due to its location in the seaside and the fact that it has insufficient infrastructures to cope with the damage to the worker and the facilities when the torrential downpour occurs in the industrial parks, it was assessed to have low adaptation ability.

Below graph are the results of calculation by applying the values of climate exposure, sensitivity and the adaptation ability in Table 1 to above Eq. 1. In all the areas except the

Table 1 Values of climate exposure, sensitivity and adaptation ability by each industrial complex (value in parentheses means the standard deviation of the climate exposure value by scenario)

\begin{tabular}{|c|c|c|c|c|c|c|}
\hline & \multicolumn{4}{|c|}{ Climate exposure } & \multirow[t]{2}{*}{ Sensitivity } & \multirow[t]{2}{*}{ Adaptation } \\
\hline & Baseline & $2020 \mathrm{~s}$ & $2050 \mathrm{~s}$ & $2100 \mathrm{~s}$ & & \\
\hline $\begin{array}{c}\text { Myeongji- } \\
\text { Noksan }\end{array}$ & 0.465 & $\begin{array}{l}0.419 \\
(0.121)\end{array}$ & $\begin{array}{l}0.506 \\
(0.175)\end{array}$ & $\begin{array}{l}0.538 \\
(0.254)\end{array}$ & 1.000 & 0.636 \\
\hline Gumi & 0.180 & $\begin{array}{l}0.190 \\
(0.075)\end{array}$ & $\begin{array}{l}0.171 \\
(0.078)\end{array}$ & $\begin{array}{l}0.212 \\
(0.043)\end{array}$ & 0.713 & 0.736 \\
\hline Gwangyang & 0.180 & $\begin{array}{l}0.479 \\
(0.148)\end{array}$ & $\begin{array}{l}0.498 \\
(0.154)\end{array}$ & $\begin{array}{l}0.522 \\
(0.283)\end{array}$ & 0.780 & 0.319 \\
\hline Ulsan Mipo & 0.513 & $\begin{array}{l}0.360 \\
(0.098)\end{array}$ & $\begin{array}{l}0.355 \\
(0.065)\end{array}$ & $\begin{array}{l}0.410 \\
(0.123)\end{array}$ & 0.704 & 0.521 \\
\hline Gunsan & 0.391 & $\begin{array}{l}0.258 \\
(0.185)\end{array}$ & $\begin{array}{l}0.295 \\
(0.046)\end{array}$ & $\begin{array}{l}0.360 \\
(0.126)\end{array}$ & 0.223 & 0.188 \\
\hline Suwon & 0.317 & $\begin{array}{l}0.285 \\
(0.089)\end{array}$ & $\begin{array}{l}0.359 \\
(0.144)\end{array}$ & $\begin{array}{l}0.323 \\
(0.106)\end{array}$ & 0.000 & 1.000 \\
\hline Songsan & 0.215 & $\begin{array}{l}0.208 \\
(0.099)\end{array}$ & $\begin{array}{l}0.270 \\
(0.082)\end{array}$ & $\begin{array}{l}0.277 \\
(0.099)\end{array}$ & 0.183 & 0.000 \\
\hline Yeosu & 0.275 & $\begin{array}{l}0.361 \\
(0.132)\end{array}$ & $\begin{array}{l}0.481 \\
(0.150)\end{array}$ & $\begin{array}{l}0.475 \\
(0.274)\end{array}$ & 0.133 & 0.488 \\
\hline
\end{tabular}


Ulsan Mipo and Gunsan, the vulnerability against the future torrential downpour was represented to be increased. Ulsan Mipo is currently the area having highest vulnerability against the torrential downpour (vulnerability assessment value is 0.290), and the vulnerability of Gumi and Gwangyang was assessed as the lowest (vulnerability value is 0.181). In 2020s, Gumi and Gwangyang were represented as the most vulnerable area against the torrential downpour (vulnerability assessment value is 0.281 ), and the vulnerability of Gumi was also assessed the lowest (vulnerability assessment value is 0.185 ). In 2050s, Myeongji-Noksan was assessed as the most vulnerable industrial parks (vulnerability assessment value is 0.290), and as the vulnerability of Gumi was least, the vulnerability value was represented as 0.179 . Myeongji-Noksan national industrial parks was the most vulnerable region for flood in 2100 's, too. Flooding vulnerability of all industrial parks is slightly increase for 2100s except Suwon. Gumi National Industrial parks is the most vulnerable low level both baseline and in the future about the flood. It was observed that the vulnerability would increase rapidly by $62.8 \%$ in Gwangyang National Industrial Park during 2020 compared to the present (Fig. 3).

\section{Discussion and conclusion}

In Korea, according to the national economic development policy, new industrial parks are being increased constantly and not only the large enterprises such as Samsung, LG, Posco but also the small and medium enterprises contribute to the economic growth of the country by entering the industrial parks. As the industrial park is where the enterprises are concentrated, to improve the production efficiency, in the area having high potential of torrential downpour, the allocation plan that excludes the business type sensitive to the precipitation is needed. In the countries such as Singapore (http://www.edb.gov.sg), Korea (http://www.kicox.or.kr), the business location information is provided at the country level. Derguti (2014) also mentioned about the conditions of industrial parks location, but he suggested the business location based on the industry location theory in the past. In the

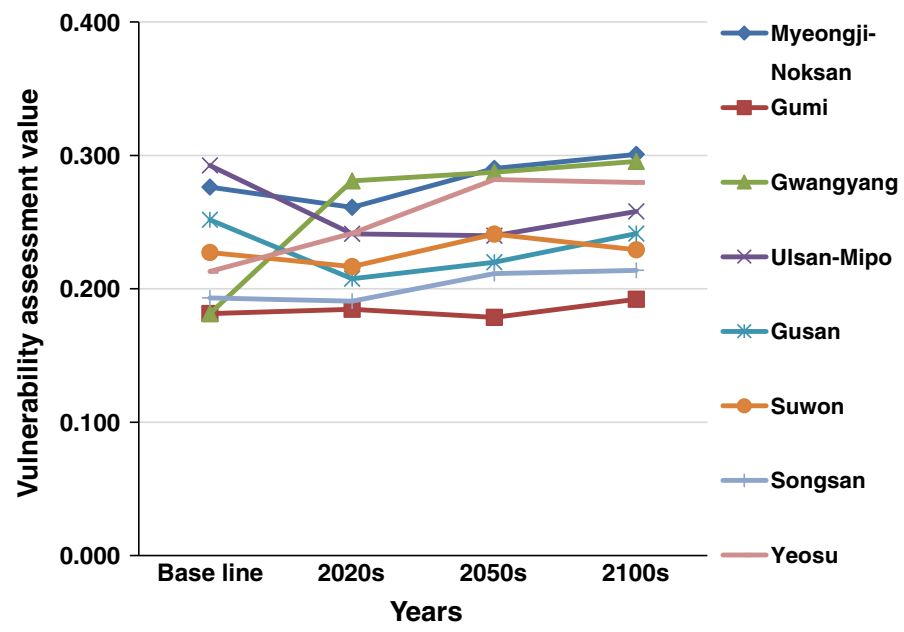

Fig. 3 Result of vulnerability assessment 
past, the government only focused on growth development policies that neglected the concept of disaster prevention and safety in the city and industrial parks. Accordingly, intensified heavy rain, landslides, pollution, heat island effects, and so on caused by climate change affect the issues of public health, energy demand and supply problems (Kang et al. 2011). A vulnerability assessment performed at the location can encourage industries to move to locations that will be damaged less. Because of the flood that occurred in Bangkok in 2011, lowland companies suffered more damage than the companies that were located in the highlands (http://edition.cnn.com/2011/10/28/world/asia/ thailand-flood/). Thus, when determining the industrial location, climate change must be considered.

Vulnerability can be divided into event-based vulnerability and structural vulnerability (Hiete and Merz 2009; Khazari et al. 2013). Both concepts are influenced by climate exposure and sensitivity and draw the degree of fragility by considering the ability to adapt. Thus, the sensitivity and the ability to adapt greatly influence the infrastructure. If the infrastructure is rearranged to consider future climate change, then the damage degree would differ with the identical risk of flood and likelihood of occurrence. In this study, Gwangyang, Myeongji-Noksan and Yeosu are the areas likely with heavy rain damage, and the most vulnerable areas are Gwangyang and Myeongji-Noksan based on the final climate change vulnerability assessment. Such vulnerability assessment results has close relationships with the potential of torrential downpour, but was analyzed that it was because as the infrastructures in the relevant areas are aged, they react sensitively to the climate exposure. Old industrial parks composed of primary production facilities that lack infrastructure, such as support facilities, avenues and medical facilities, produced uncomfortable worker commutes and production distribution.

In addition, the industrial parks having high potential of climate exposure are located mostly in the south coast, which can be considered as the atmospheric general circulation and the geographical factor. In Korea, the area having high potential of climate exposure was analyzed as the vulnerable area, and since the vulnerability assessment was performed by obtaining the mean value from the value of each scenario by year, the future vulnerability of the industrial park does not increase greatly but the whole industrial park represented the trend that the vulnerability is increased in average. The industrial parks subject to assessment were assessed with $0.1-0.3$ of vulnerability score, and although the actual value is not great, in the area scored with 0.2 or higher, there is the record that the great damage has incurred by the flood from the past to the present. Therefore, the adaptation ability needs to be increased as the value is closer to 0.3 .

Currently, in some areas in Korea the extreme precipitation by typhoon is being increased compared to the past, which coincides with the results that particularly in the south coast, the extreme precipitation was estimated greatly (Park et al. 2008). The area assessed as the vulnerable area in the vulnerability assessment results actually received the damage by the large precipitation and strong winds.

In 2003, including direct and indirect damage by the large precipitation and the strong winds caused by the typhoon Maemi, Myeongji-Noksan National Industrial Park (vulnerability assessment value of baseline is 0.276 ) received the damage equivalent to $50,719,972$ dollar and 338 enterprises within the industrial park received the damage. Yeosu (vulnerability assessment value of baseline is 0.213 ) received the damage equivalent to 50,719,971 dollar (internal data of Korea Industrial Complex Corporation, Sep, 2003) and 31 enterprises received the damage. In Ulsan Industrial Park (vulnerability assessment value of baseline is 0.292) approximately 86 enterprises received the damage, which amounts to 31,357,686 dollar (internal data of Korea Industrial Complex Corporation, Jul, 
2003). In Myeongji-Noksan, some factories were flooded by the torrential downpour of 180-200 mm per hour in 2009, too (internal data of Korea Industrial Complex Corporation, Jul, 2009).

In Gunsan (vulnerability assessment value of baseline is 0.252 ), by the torrential downpour of maximum $137 \mathrm{~mm} / \mathrm{h}$ in 2012 (accumulated precipitation: $439 \mathrm{~mm}$ ), 63 enterprises received the damage of $16,539,890$ dollar. The drain capacity of the existing infrastructure was exceeded by such heavy rain (in case of Gunsan, $43 \mathrm{~mm} / \mathrm{h}$ ), and the grass and fallen leaves flowed into drainage treatment facilities clogging the entrance of the storm sewer; the flooding within the complex was aggravated. The enterprises in the lower area and around the river received damages such as flooding, electric leakage, and the roads within the complex were washed away and the phenomenon that the ground around the wastewater treatment plant was sunk occurred (internal data of Korea Industrial Complex Corporation, Jul, 2012).

Vulnerability assessment is the method to assess the degree of vulnerability against the heavy rain in the region with the infrastructures and location conditions of the industrial parks based on the potential of heavy rain considering the present and the future. In this study, the assessment was conducted by selecting eight industrial parks reflecting the important geographical characteristics of Korea among the industrial parks distributed all across the nation as of now, and such a method would help to increase climate change adaptation ability by conducting the vulnerability assessment against the torrential downpour for the entire nation.

In case of the industrial park representing vulnerability assessment value more than 0.2 , the vulnerability can be lowered by increasing the adaptation ability. For that method, in case of using the indicators in this study, the future capacity for the precipitation needs to be considered in establishing emergency power supply facilities, creating a buffer zone around waste disposal facilities, increasing the green area, diversifying transport facilities, diversifying raw material supplies, etc. To prevent the flooding, if the adaptation ability of the enterprise and the industrial park to the climate change is increased by performing the research on the potential of torrential downpour in the region, improving infrastructures long term such as expansion of reservoir or drain pump, and by investing actively in the research prevent the flooding, the damage by the climate change to the industry sector can be reduced and the economic stability can be promoted.

This study was performed under the assumption that each industrial park represents the same characteristics, but since the major business type and the characteristics of the enterprises by each industrial park are actually different, in future, the study needs to be performed by reflecting such characteristics. Particularly, the oil refining has great influence on the economy of each country in the world and was assessed as vulnerable in the export and import of Korea (Gupta 2008). Oil refining and the petro-chemistry are the business vulnerable to the climate change (Khazari et al. 2013). As such, since there are the characteristics of the business that affect the climate, if such characteristics are reflected, the study would become a much practical study.

Acknowledgments This work was supported by Korea Energy Agency, Ministry of Trade, Industry and Energy, the BK 21 Plus Project in 2015 (Seoul National University Interdisciplinary Program in Landscape Architecture, Global Leadership Program toward innovative green infrastructure) and the Development of Economic Assessment Technique for Climate Change Impact and Adaptation Considering Uncertainties (Korea Ministry of Environment, Project No. 2014001310010).

Open Access This article is distributed under the terms of the Creative Commons Attribution 4.0 International License (http://creativecommons.org/licenses/by/4.0/), which permits unrestricted use, distribution, 
and reproduction in any medium, provided you give appropriate credit to the original author(s) and the source, provide a link to the Creative Commons license, and indicate if changes were made.

\section{References}

Ager WN (2006) Vulnerability. Glob Environ Change 16(3):57-63

Aldum N, Duggie J, Robson BJ (2013) Climate change adaptation support tools in Australia. Reg Environ Change 14(1):401-411

Bae CY, Oh YG, Baek GH, Choi KL, Lee SH, Lee DK (2013) A study on climate change vulnerability assessment index and weights of industrial sectors-focused on petroleum and automobile industries. Korea Plan As 48(2):313-328

Brooks N (2003) Vulnerability, risk and adaptation: a conceptual framework, working paper 38, Tyndall center for climate change research. www.tyndall.ac.uk

Derguti A (2014) Importance of locations in the industrial parks-Ferizaj case study. J Int Sci Publ 8:641-649

Fussel HM, Klein RJT (2006) Climate change vulnerability assessment: an evolution of conceptual thinking. Clim Change 75:301-329

Gallopin GC (2006) Linkages between vulnerability, resilience, and adaptive capacity. Glob Environ Change 16:293-303

Gupta E (2008) Oil vulnerability index of oil-importing countries. Energy Policy 36(3):1195-1211

Han KJ (2007) The economic impact of climate change on the industrial sector. KIET Ind Econ 108:52-66

Han HJ, Ahn SE, Yoo GY, Jo GW, Lee SY, Kim JE, Ahn SW, Na YE, Kim MH, Kim GN, Son YH, Jo YS, Jung IO (2007) Climate change impact assessment And building adaptive systems III. Korea Environ Inst: $137-357$

Hiete M, Merz M (2009) An indicator framework to assess the vulnerability of industrial sectors against indirect disaster losses. International ISCRAM conference, Gothenburg

Intergovernmental Panel on Climate Change (IPCC) (2007) Climate change 2007-impacts, adaptation and vulnerability In: Parry ML, Canziani OF, Palutikof JP, van der Linden PJ, Hanson CE (eds) Contribution o working group II to the fourth assessment report of the international panel on climate change. Cambridge University Press, Cambridge

Islam MN, Malak MA, Islam MN (2013) Community-based disaster risk and vulnerability models of a coastal municipality in Bangladesh. Nat Hazards 69:2083-2103

Janssen MA, Schoon MI, Ke W, Borner K (2006) Scholarly networks on resilience, vulnerability and adaptation within the human dimensions of global environmental change. Glob Environ Change 16

Jo HY (2005) Status and policy issues of industrial complex. Ind Locat 9:1-10

Kang JE, Lee MJ, Gu YS, Jo GW, Lee JW (2011) Urban renewal strategy for adapting to climate change: use of green infrastructure on flood mitigation. Report of Korean Environment Institute, pp 7-85

Khazari B, Merz M, Schulz C, Borst D (2013) An integrated indicator framework for spatial assessment of industrial and social vulnerability to indirect disaster losses. Nat Hazards 67:145-167

Kim DG (2011) Industrial Park redevelopment, continue in the next year. Busan Dev Forum 132:23-24

Kim MK, Han MS, Jang DH, Baek SG, Lee WS, Kim YH, Kim S (2012) Production technique of observation grid data of $1 \mathrm{~km}$ resolution. Weather Res 7(1):55-68

Kim MK, Lee DH, Kim J (2013) Production and validation of daily grid data with $1 \mathrm{~km}$ resolution in South Korea. Weather Res 8(1):13-25

Ko JG (2011) A study on climate change vulnerability types and adaptation in local government: with cases from Gyeonggi-Do. Korean Soc Public Adm 8:93-118

Korea industrial complex corporation (2014) Industrial complex location bulletin

Korean Ministry of Knowledge Economy (2010) A study on establishing strategy roadmap of climate change adaptation in industrial sector. Gwacheon 10-78

Lee DK, Kim HG, Baek GH, Seo CW, Kim JU, Song CK, Yu JA (2012) Vulnerability assessment of landslide by heavy rain to establish climate change adaptation plan for local governments. Clim Change Res 3(1):39-50

Leiter AM, Oberhofer H, Raschky PA (2009) Creative disaster? Flooding effects on capital, labour and productivity within European firms. Environ Res Econ 43:333-350

McCarthy JJ, Canziani OF, Leary NA, Dokken DJ, White KS (eds) (2001) Climate change 2001: impacts, adaptation and vulnerability. Contribution of working group II to the third assessment report of the intergovernmental panel on climate change. Cambridge University Press, Cambridge

Merz M, Hiete M, Comes T, Schultmann F (2013) A composite indicator model to assess natural disaster risks in industry on a spatial level. J Risk Res 16(9):1077-1099 
Ministry of environment (2011) Korea climate change assessment report 2010

Mueller SA, Carlile A, Bras B, ThomasAN Susan MR, Heidi LM, Kim HC, Wallington TJ (2015) Requirements for water assessment tools: an automotive industry perspective. Water Res Ind 9:30-44

Myeong SJ, Yi D (2009) Assessing vulnerability to climate change of the physical infrastructure in Korea through a survey of professionals. Environ Impact Assess 18(6):347-357

O'Brien KL, Leichenko RM (2000) Double exposure : assessing the impacts of climate change within the context of economic globalization. Glob Environ Change 10:221-232

O’Brien K, Leichenko R, Kelkar U, Venema H, Aandahl G, Tompkins H, Javed A, Bhadwal S, Barg S, Nygaard L, West J (2004) Clim Environ Change 14:303-313

Park CY, Moon JY, Cha EJ, Yun WT, Choi YE (2008) Recent change in summer precipitation characteristics over South Korea. J Korean Geogr Soc 43(3):324-336

Shim WB, Ji SH (2012) Heavy rain disaster prevention and urban vulnerability analysis of climate change. Korea Res Inst Hum Settl Policy Brief 388:1-8

Smit B, Wandel J (2006) Adaptation, adaptive, capacity and vulnerability. Glob Environ Change 16(3):282-292

Sullivan C, Meigh (2005) Targeting attention on local vulnerabilities using and integrated index approach: the example of the Climate vulnerability index. Water Sci Technol 51(5):69-78

Tixier J, Dusserre G, Salvi O, Gaston D (2002) Review of 62 risk analysis methodologies of industrial plants. J Loss Prev Process Ind 15:291-303

Turner BL, Kasperson RE, Matson PA, McCarthy JJ, Corell RW, Christensen L, Eckley N, Kasperson JX, Fuers A, Martello ML, Polsky C, Pulsipher A, Schiller A (2003) A framework for vulnerability analysis in sustainability science. Natl Acad Sci 100(14):8074-8079

Wall E, Marzall K (2006) Adaptive capacity for climate change in Canadian rural communities. Local Environ 99(4):373-397

White GF, Haas JE (1975) Assessment of research on Natural Hazards. MIT Press, Cambridge, MA, pp 22-50

MA Yusuf AA, Francisco H (2009) Climate change vulnerability mapping for Southeast Asia. Economy and environment program for Southeast Asia, Singapore

\section{Other sources}

Article 6, Chapter 3 of Industrial Sites and Development Act (Industrial location policy division, Ministry of Land, Infrastructure and Transport, 044-201-3676, 3677)

e- Country index: http://www.index.go.kr/potal/main/EachDtlPageDetail.do?idx_cd=1628

CNN news October 29, 2011: http://edition.cnn.com/2011/10/28/world/asia/thailand-flood/

Newsflash off-Gunsan Industrial parks cumulative rainfall $432 \mathrm{~mm}$ : http://onkweather.com/bbs/board. php?bo_table=eco2\&wr_id=488

Information of Industrial parks location in Singapore: http://www.edb.gov.sg

Information of Industrial parks location in South Korea: http://www.kicox.or.kr

Internal data of Korea Industrial Complex Corporation, Jul, 2003

Internal data of Korea Industrial Complex Corporation, Sep, 2003

Internal data of Korea Industrial Complex Corporation, Jul, 2009

Internal data of Korea Industrial Complex Corporation, Jul, 2012 